\title{
Drug-disease interactions of differentially expressed genes in COVID-19 liver samples: an in-silico analysis
}

\author{
Suzan Omar Rasool ${ }^{1}$, Ata Miræaei Nahr ${ }^{2}$, Sania Eskandari ${ }^{3}$, Milad Hosseinzadeh ${ }^{4}$, \\ Soheila Asoudeh Moghanloo ${ }^{5}$ and Farnoosh Ebrahimsadeh ${ }^{6}$ \\ ${ }^{1}$ Department of Clinical Pharmacy, College of Pharmacy, University of Duhok, Kurdistan \\ Region, Iraq. \\ ${ }^{2}$ School of Medical Sciences and Health Services, Tabriz University of Medical Sciences, \\ Tabriz, Iran. \\ ${ }^{3}$ Department of Genetic, Tabriz Branch, Islamic Azad University, Tabriz, Iran. \\ ${ }^{4}$ School of Medical Sciences and Health Services, Zabol University of Medical Sciences, \\ Zabol, Iran. \\ ${ }^{5}$ Department of Genetic Enginering, Marvdasht Branch, Islamic Azad University, \\ Marvdasht. \\ ${ }^{6}$ Department of Internal Medicine, Faculty of Medicine, Mashhad University of Medical \\ Sciences, Mashhad, Iran.
}

Key words: COVID-19; liver; cytochrome P450; gene expression.

\begin{abstract}
While COVID-19 liver injuries have been reported in various studies, concerns are raised about disease-drug reactions in COVID-19 patients. In this study, we examined the hypothesis of gene-disease interactions in an in-silico model of gene expression to seek changes in cytochrome P450 genes. The Gene Expression Omnibus dataset of the liver autopsy in deceased COVID-19 patients (GSE150316) was used in this study. Non-alcoholic fatty liver biopsies were used as the control (GSE167523). Besides, gene expression analysis was performed using the DESeq/EdgeR method. The GO databases were used, and the paths were set at $\mathrm{p}<0.05$. The drug-gene interaction database (DGIdb) was searched for interactions. According to the results, 5,147 genes were downregulated, and 5,122 genes were upregulated in SARS-CoV-2 compared to healthy livers. Compared to the cytochromes, 34 cytochromes were downregulated, while 4 cytochromes were upregulated among the detected differentially expressed genes (DEG). The drug-gene interaction database (DGIdb) provided a list of medications with potential interactions with COVID-19 as well as metacetamol, phenethyl isocyanate, amodiaquine, spironolactone, amiloride, acenocoumarol, clopidogrel,
\end{abstract}

Corresponding author: Farnoosh Ebrahimzadeh. Department of Internal Medicine, Faculty of Medicine, Mashhad University of Medical Sciences, Mashhad, Iran. Email: ebrahimzadehf@mums.ac.ir 
phenprocoumon, trimipramine, phenazepam, etc. Besides, dietary compounds of isoflavones, valerian, and coumarin, as well as eaffeine metabolism were shown to have possible interactions with COVID-19 disease. Our study showed that expression levels of cytochrome P450 genes could get altered following COVID-19. In addition, a drug-disease interaction list is recommended to be used for evaluations in clinical considerations in further studies.

\title{
Interacciones fármaco -enfermedad de genes diferencialmente expresados en muestras de higado de COVID-19: un análisis in-silico.
}

\author{
Invest Clin 2021; 62 (4): 316-324
}

Palabras clave: COVID-19; hígado; citocromo P450; expresión génica.

Resumen. Mientras que se han informado sobre lesiones hepáticas por COVID-19 en diversos estudios, las preocupaciones se elevan acerca de las reacciones enfermedad-fármaco en los pacientes con COVID-19. En este estudio, investigamos la hipótesis de las interacciones gen-enfermedad en un modelo in-silico de la expresión génica para buscar los cambios en los genes del citocromo P450. En este estudio se utilizó el conjunto de datos Ómnibus de la Expresión Génica de la autopsia hepática en los pacientes fallecidos por COVID-19 (GSE150316). Las biopsias de hígado graso no alcohólico se utilizaron como controles (GSE167523). Además, el análisis de la expresión génica se realizó mediante el método DESeq / EdǵeR. Se utilizaron las bases de datos GO y las rutas fueron ajustadas en $\mathrm{p}<0,05$. La base de datos de la interacción fármacogen (DGIdb) fue investigada para las interacciones. Según los resultados, 5.147 genes se regularon a la baja y 5.122 genes se regularon al alza en el SARS-CoV-2 en comparación con los hígados sanos. En comparación con los citocromos, 34 citocromos se regularon a la baja, mientras que 4 citocromos fueron regulados al alza entre la expresión de los genes detectados diferencialmente (DEG). La base de datos de la interacción fármaco-gen (DGIdb) proporcionó una lista de medicamentos con las interacciones potenciales con COVID-19, así como con metacetamol, fenetilo isocianato, amodiaquina, espironolactona, amilorida, acenocumarol, clopidogrel, fenprocoumon, trimipramina, fenazepam, etc. También, los compuestos dietéticos de isoflavonas, valeriana y cumarina, así como el metabolismo de la cafeína han mostrado tener posibles interacciones con la enfermedad COVID-19. Nuestro estudio demostró que los niveles de la expresión de los genes del citocromo P450 podrían quedar alterados siguiendo COVID-19. Además, se recomienda utilizar una lista de fármaco-enfermedad interacción para evaluar en las consideraciones clínicas en otros estudios adicionales.

Received: 15-05-2021 Accepted: 06-07-2021

Vol. 62(4): 316 - 324, 2021 


\section{INTRODUCTION}

COVID-19 manifestations in the liver have been recently reported. According to available evidence, $2-11 \%$ of COVID-19 patients develop liver disease. In $14-53 \%$ of the cases, abnormal levels of alanine aminotransferase (ALT) and aspartate aminotransferase (AST) have been seen during progression of the disease (1). In mild cases of COVID-19, liver damage is often transient and can return to its normal state without any special treatment. However, patients with severe COVID-19 disease appear to have more severe liver function disorders (2). Liver damage in patients with SARS-CoV-2 infection could be directly due to viral infection of liver cells (3) and immune-mediated inflammations, such as cytokine storm. In addition, liver damage could be due to toxicity of prescribed medications for COVID-19 (4). In patients with critical forms of COVID-19, it may lead to liver failure $(5,6)$. Many concerns have been raised about the possibility of significant disease-drug interactions in COVID-19 patients through modulations of Cytochrome P450s, as Ghiaty et al. reported (7). Human cytochrome P450 enzymes are monooxygenases playing a decisive role in the synthesis of cholesterol, steroids, and other lipids, as well as in detoxification and metabolism of drugs and environmental chemicals. Any changes in expression of the cytochrome $\mathrm{P} 450$ gene or its post-transcriptional level might dysregulate its function (8). The cytochrome P450 enzyme is responsible for metabolizing a wide range of internal and external organic compounds. Besides, many drug compounds involved in treatment are substrates for this enzyme. This study aims to examine the hypothesis of gene-disease interactions in an in-silico model of gene expressions to seek changes in cytochrome P450 genes.

\section{MATERIALS AND METHODS}

We conducted a meta-analysis of Gene Expression Omnibus (GEO) data on the livers of COVID-19 patients. Datasets of COVID-19 patients were searched using the keywords of "COVID-19", "SARS-CoV-2", and "new Coronavirus" through a GEO search. The GEO databases were chosen from 25 available sources based on the inclusion criterion that was available gene expression data of the livers of COVID-19 individuals. Based on the similarities to the COVID-19 datasets chosen, control datasets were quarried. Accordingly, raw read counts (Illumina platforms) of liver autopsy in deceased COVID-19 patients of the GSE150316 GEO dataset were included with three samples in this study. Besides, GSE167523 samples of humans' non-alcoholic fatty liver disease were used as controls.

Gene expression analysis was performed using the DESeq/EdgeR method, via iDEPRShiny software (9). Lowly expressed genes were excluded from the dataset through data processing. Next, gene IDs were converted to a similar format and data were log transformed for PCA analysis. Besides, differentially expressed genes (DEGs) were detected using the DESeq2 package with the false detection threshold of (FDR) $<0.1$ and a change equal and higher than 2 .

To identify important biological pathways based on common genes affected in the two datasets, GO databases were used, with the paths of $\mathrm{p}<0.05$, according to hypergeometric analysis, having been reported as affected paths. To identify biological pathways involved in the studied disease, the drug-gene interaction database (DGIdb) and GO were used. To interpret the list of the genes based on GO databases, hypergeometric statistic tests were used to read the GO pathways and to build a gene expression regulation network. 


\section{RESULTS}

\section{Processing}

A total of 26,364 genes were evaluated in 10 samples with the settings of the counts per million reads mapped $(\mathrm{CPM})=$ 0.5 . The difference between replicates in the SARS-CoV-2 samples compared to healthy livers showed a significant alteration to the expression of hundreds of genes in SARS$\mathrm{CoV}-2$ infected livers versus the control samples based on the analysis of the principal components (PCA) that explained for $67 \%$ of the variance difference between SARS-CoV-2 and control samples (Fiǵ. 1A). Accordingly, SARS-CoV-2 led to an extensive transcriptional response in the liver (Fig. 1B).

\section{Differentially expressed genes}

Finally, 5,147 and 5,122 genes were detected to have been downregulated and upregulated, respectively, in SARS-CoV-2 compared to healthy livers (Fig. 2A). Next, differentially expressed genes that were significantly downregulated were subjected to enrichment analysis based on the GO data- base. The 10 most significant pathways in both down- and up-regulated genes are listed in Table I.

\section{Drug-gene interactions}

Cytochromes in the livers of COVID-19 patients were examined and quarried. According to the results, 34 cytochromes of CYP2E1, CYP3A4, CYP2C9, CYP1A2, CYP2C8, CYP2A6, CYP4A11, CYP4F2, CYP4A22, CYP2C18, GYP8B1, CYP2A7, CYP4F3, CYP7A1, CYP2C19, CYP2B6, CYP1A1, CYP2D7, CYP4F11, GYP27A1, CYP3A43, CYP51A1, CYP4F22, CYP4F12, CYP3A5, CYP26A1, CYP39A1, CYP11A1, CYP4V2, CYP3A7, GYP17A1, CYP3A7, GYP3A7-CYP3A51P, and CYP21A2 were downregulated among the detected DEGs (Table II). In contrast, 4 cytochromes of CYP4B1, CYP2D6, CYP24A1, and CYP4F29P were upregulated.

The drug-gene interaction database (DGIdb) was quarried. As Table II shows, drugs related to these cytochromes were extracted. Besides, drug-gene interactions with the interaction score of higher than 1 were included.

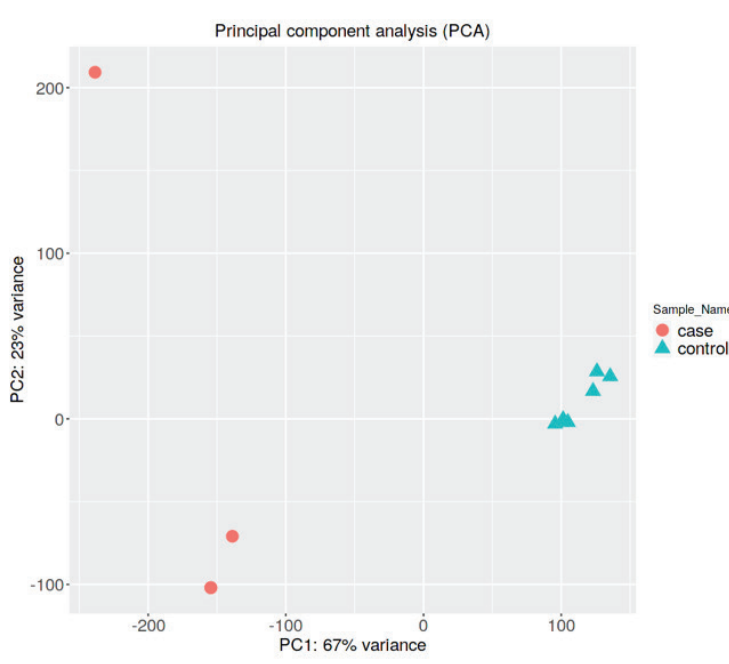

(a)

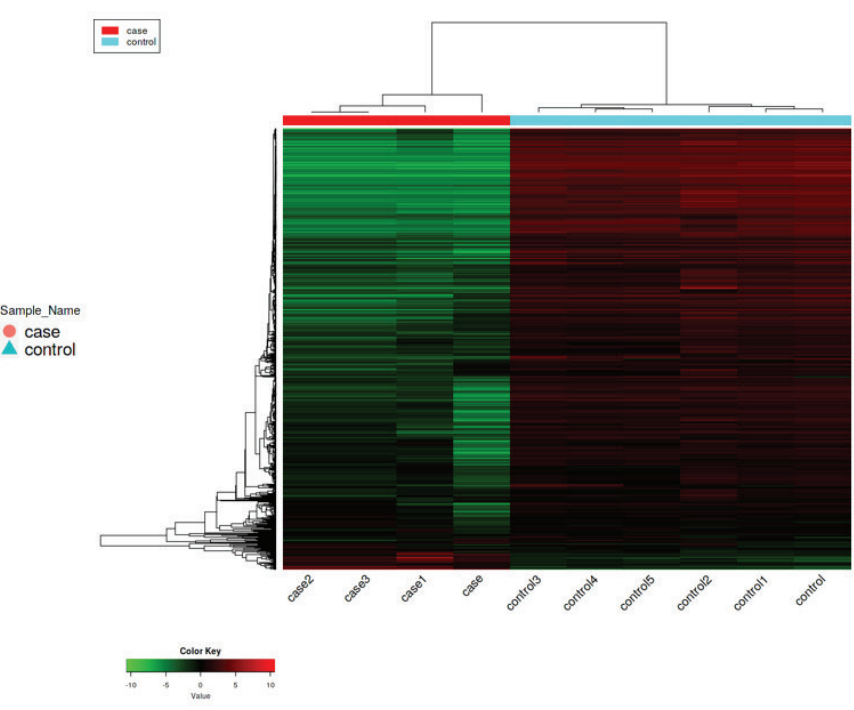

(b)

Fig. 1. (A) Principal components (PCA) analysis; (B) Heatmap diagram. 


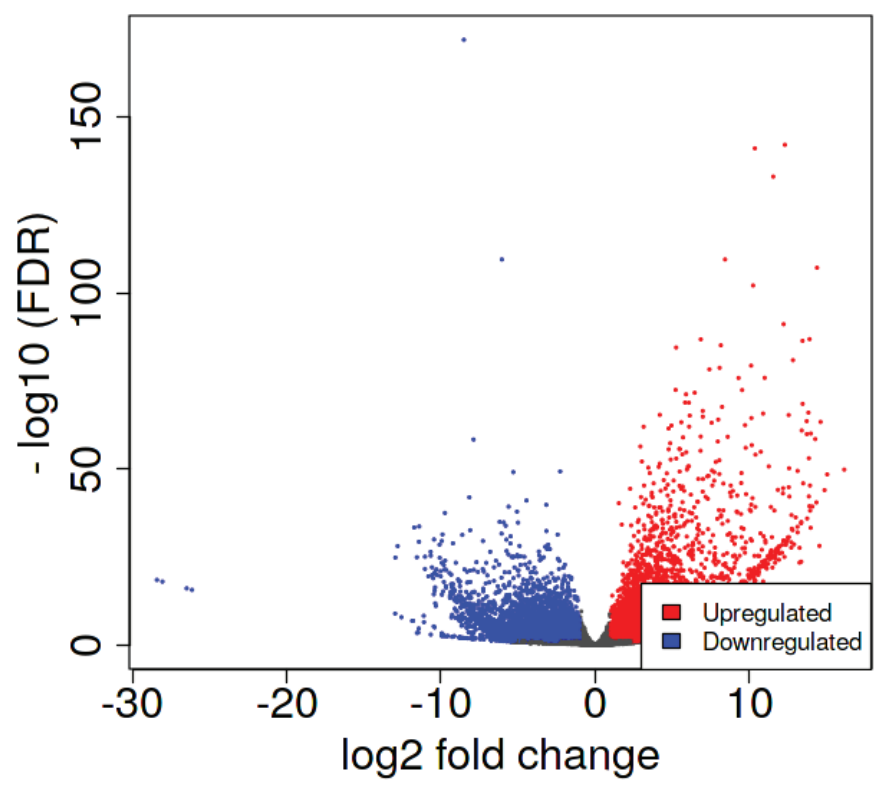

Fig. 2. (A) Volcano plot of differentially expressed genes.

TABLE I

GO DATABASE PATHWAY ENRICHMENT.

\begin{tabular}{|c|c|c|c|c|c|}
\hline \multicolumn{3}{|c|}{ Upregulated } & \multicolumn{3}{|c|}{ Downregulated } \\
\hline Number of Genes & P-value & $\begin{array}{l}\text { Number } \\
\text { of Genes }\end{array}$ & Pathways & P-value & $\begin{array}{l}\text { Number } \\
\text { of Genes }\end{array}$ \\
\hline $\begin{array}{l}\text { Anatomical structure } \\
\text { morphogenesis }\end{array}$ & 6.3E-71 & 806 & $\begin{array}{l}\text { Small molecule } \\
\text { metabolic process }\end{array}$ & $2.7 \mathrm{E}-155$ & 973 \\
\hline $\begin{array}{l}\text { Movement of cells or } \\
\text { subcellular component }\end{array}$ & $1.3 \mathrm{E}-68$ & 677 & $\begin{array}{l}\text { Organic acid } \\
\text { metabolic process }\end{array}$ & 7.1E-109 & 617 \\
\hline Locomotion & $1.4 \mathrm{E}-57$ & 587 & $\begin{array}{l}\text { Carboxylic acid } \\
\text { metabolic process }\end{array}$ & 7.1E-109 & 580 \\
\hline $\begin{array}{l}\text { Circulatory system } \\
\text { development }\end{array}$ & $2.3 \mathrm{E}-55$ & 387 & $\begin{array}{l}\text { Oxoacid metabolic } \\
\text { process }\end{array}$ & $1.6 \mathrm{E}-107$ & 608 \\
\hline Biological adhesion & $6.8 \mathrm{E}-54$ & 505 & Oxidation-reduction process & $6.9 \mathrm{E}-104$ & 552 \\
\hline Cell adhesion & $2.1 \mathrm{E}-53$ & 502 & Catabolic process & $9.4 \mathrm{E}-84$ & 1049 \\
\hline Cell motility & $2.1 \mathrm{E}-53$ & 531 & $\begin{array}{l}\text { Organic substance } \\
\text { catabolic process }\end{array}$ & $9.1 \mathrm{E}-79$ & 900 \\
\hline Cell migration & $3.8 \mathrm{E}-52$ & 487 & $\begin{array}{c}\text { Small molecule } \\
\text { biosynthetic process }\end{array}$ & $3.2 \mathrm{E}-76$ & 386 \\
\hline $\begin{array}{l}\text { Regulation of developmental } \\
\text { process }\end{array}$ & $4 \mathrm{E}-52$ & 754 & $\begin{array}{l}\text { Lipid metabolic } \\
\text { process }\end{array}$ & $2.3 \mathrm{E}-75$ & 643 \\
\hline $\begin{array}{l}\text { Anatomical structure } \\
\text { formation involved in }\end{array}$ & $5.1 \mathrm{E}-51$ & 393 & $\begin{array}{c}\text { Cellular catabolic } \\
\text { process }\end{array}$ & $3.1 \mathrm{E}-75$ & 918 \\
\hline
\end{tabular}


TABLE II

DRUG-GENE INTERACTIONS.

\begin{tabular}{|c|c|c|c|}
\hline Symbol & $\begin{array}{l}\log ^{2} \text { Fold } \\
\text { Change }\end{array}$ & $\begin{array}{c}\text { Adjusted } \\
\text { P-value }\end{array}$ & Drug name (Interaction Score) [reference] \\
\hline CYP2E1 & -16.15 & $1.70 \mathrm{E}-50$ & $\begin{array}{c}\text { METACETAMOL }(5.55)(10) \\
\text { VALERIAN }(2.77)(11) \\
\text { PERFLUBRON }(5.55)(12) \\
\text { PHENETHYL ISOCYANATE }(5.55)(13) \\
\text { BRADANICLINE }(1.39)(14) \\
\text { ISOFLAVONE }(1.85)(15)\end{array}$ \\
\hline CYP3A4 & -13.89 & $4.04 \mathrm{E}-40$ & - \\
\hline CYP2C9 & -13.35 & $3.14 \mathrm{E}-35$ & - \\
\hline CYP1A2 & -12.71 & $2.62 \mathrm{E}-28$ & - \\
\hline GYP2C8 & -12.55 & $1.67 \mathrm{E}-45$ & $\begin{array}{l}\text { AMODIAQUINE (2.36) (16-17) } \\
\text { CERIVASTATIN }(1.77)(18-19)\end{array}$ \\
\hline CYP2A6 & -11.84 & $1.01 \mathrm{E}-15$ & $\begin{array}{l}\text { COUMARIN }(4.21)(20) \\
\text { CAFFEINE }(4.08)(21) \\
\text { LETROZOLE }(9.57)(22) \\
\text { 3-FORMYLINDOLE }(5.32)(23) \\
\text { CHEMBL1770735 }(5.32)(24) \\
\text { IFOSFAMIDE }(2.07)(25)\end{array}$ \\
\hline CYP4A11 & -11.62 & $7.24 \mathrm{E}-39$ & $\begin{array}{l}\text { SPIRONOLACTONE (1.68) [None found] } \\
\text { AMILORIDE (2.13) [None found] }\end{array}$ \\
\hline CYP4F2 & -10.97 & $2.68 \mathrm{E}-24$ & $\begin{array}{c}\text { ACENOCOUMAROL }(23.92)(26) \\
\text { CLOPIDOGREL }(1.2) \text { [ None found] } \\
\text { PAFURAMIDINE MALEATE }(7.97) \text { [None found] } \\
\text { PHENPROCOUMON }(3.42)(27)\end{array}$ \\
\hline CYP4B1 & +10.32 & $9.33 \mathrm{E}-12$ & THALIDOMIDE (1.82) (28-29) \\
\hline CYP2D6 & +6.322 & $1.77 \mathrm{E}-03$ & SPARTEINE(1.84)(30) \\
\hline CYP24A1 & +6.25 & $2.58 \mathrm{E}-02$ & $\begin{array}{l}\text { LUNACALCIPOL (12.76) [None found] } \\
\text { CHEMBL255088 }(4.25) \text { [None found] } \\
\text { TELAPREVIR }(4.25)(31) \\
\text { DEFERASIROX }(3.83)(32) \\
\text { CALCITRIOL }(2.32)(33)\end{array}$ \\
\hline
\end{tabular}

\section{DISCUSSION}

This study showed that the function of the cytochrome $\mathrm{P} 450$ genes could get altered following COVID-19. A comparison of normal liver cells and SARS-CoV-2-infected hepatic cells showed a decreased expression level of some of the cytochrome P450 genes. Detoxification is a phenomenon that eliminates toxins from the body, which occurs in two phases. Accordingly, phase 1 is catalyzed by cytochrome p450. Products produced in phase 1 are mainly active oxygen and compounds causing damage to organs. These compounds are inactivated by phase 2 enzymes. More than $75 \%$ of detoxification occurs in the liver; however, it occurs in the intestinal mucosa in some cases.

According to Relats et al. (34), numerous food products react with eytochrome P450 enzyme-metabolized substances of DGIdb. Quarries also showed significant inter-

Vol. 62(4): 316 - 324, 2021 
actions with some nutrients, while its clinical significance is ambiguous.

Our search at DGIdb showed possible effects of COVID-19 on isoflavones, valerian, coumarin, and caffeine metabolism. Most of nutrients could be inhibitors of cytochromes. Accordingly, they reduce metabolic activity of the cytochrome P450 enzyme.

Medications listed in Table II were found to have interactions with cytochrome $\mathrm{P} 450$ enzymes. However, these results require further clinical research to confirm such interactions. Our results support the idea of disease-drug interactions in COVID-19 patients.

The most significant interactions were found to be those of CYP4F2 with acenocoumarol, with the interaction score of 23.92 followed by letrozole with the interaction score of 9.57 .

On the other hand, with the advent of COVID-19, many people may seek herbal, supplementary, or dietary treatments as there is no definitive treatment for COVID-19 (11). Our study found some consistency with the in-vivo study of the Gurley et al. (11), which showed interactions of the black cohosh and valerian with human cytochromes of P450, 1A2, 2D6, $2 \mathrm{E} 1$, and $3 \mathrm{~A} 4 / 5$ phenotypes.

\section{Limitations of the study}

While most similar control datasets were in non-alcoholic fatty liver disease, there could be some bias towards results of the study as non-alcoholic fatty liver may have different forms of gene expression with completely healthy samples. Besides, lots of confounding factors could be effective as results of various studies show that genetic polymorphisms might affect the body's response to COVID-19 $(35,36)$.

The present study was a comprehensive analysis of COVID-19 disease-gene interactions that could contribute to adverse effects. The identified differentially expressing genes in this study might contribute to interactions with COVID-19 and present a drug-disease-interaction list to be considered for further realistic clinical research.

\section{REFERENCES}

1. Zhang $\mathrm{C}$, Shi $\mathrm{L}$, Wang FS. Liver injury in COVID-19: management and challenges. Lancet Gastroenterol Hepatol 2020:5(5):428430.

2. Cai Q, Huang D, Yu H, Zhu Z, Xia Z, Su Y, Li Z, Zhou G, Gou J, Qu J, Sun Y. Characteristics of Liver Tests in COVID-19 Patients. J Hepatol 2020.

3. Afra HS, Amiri-Dashatan N, Ghorbani F, Maleki I, Rezaei-Tavirani M. Positive association between severity of COVID-19 infection and liver damage: a systematic review and meta-analysis. Gastroenterol Hepatol Bed Bench 2020;13(4):292.

4. Wang $\mathrm{Y}$, Liu $\mathrm{S}$, Liu $\mathrm{H}$, Li W, Lin F, Jiang $\mathrm{L}$, Li X, Xu P, Zhang L, Zhao L, Cao Y. SARSCoV-2 infection of the liver directly contributes to hepatic impairment in patients with COVID-19. J Hepatol 2020:73(4):807-816.

5. Alqahtani SA, Schattenberg JM. Liver injury in COVID-19: The current evidence. United European Gastroenterol J 2020: 8(5):509-519.

6. Gurala D, Al Moussawi H, Philipose J, Abergel JR. Acute liver failure in a COVID-19 patient without any preexisting liver disease. Cureus 2020:12(8).

7. El-Ghiaty MA, Shoieb SM, El-Kadi AO. Cytochrome P450-mediated drug interactions in COVID-19 patients: Current findings and possible mechanisms. Med Hypotheses 2020;144:110033.

8. Guengerich FP, Wilkey CJ, Phan TT. Human cytochrome P450 enzymes bind drugs and other substrates mainly through conformational-selection modes. J Biol Chem 2019:294(28):10928-41.

9. Ge SX, Son EW, Yao R. iDEP: an integrated web application for differential expression and pathway analysis of RNA-Seq data. BMC bioinform 2018:19(1):534.

10. Harrelson JP, Stamper BD, Chapman JD, Goodlett DR, Nelson SD. Covalent modification and time-dependent inhibition of human CYP2E1 by the meta-isomer of acetaminophen. Drug Metab Dispos 2012:40(8):1460-1465.

11. Gurley BJ, Gardner SF, Hubbard MA, Williams DK, Gentry WB, Khan IA, Shah A. In vivo effects of goldenseal, kava kava, black 
cohosh, and valerian on human eytochrome $\mathrm{P} 450$ 1A2, 2D6, 2E1, and 3A4/5 phenotypes. Clin Pharmacol Ther 2005:77(5):415426.

12. Obraztsov VV, AIu G, Shekhtman DG, Sklifas AN, Makarov KN. Interaction of perfluoroctylbromide with liver microsomal monooxygenase. Biokhimiia (Moscow, Russia) 1993:58(8):1234-1239.

13. Yoshigae Y, Sridar C, Kent UM, Hollenberg PF. The inactivation of human CYP2E1 by phenethyl isothiocyanate, a naturally occurring chemopreventive agent, and its oxidative bioactivation. Drug Metab Dispos 2013:41(4):858-869.

14. Mazurov AA, Kombo DC, Hauser TA, Miao L, Dull G, Genus JF, Fedorov NB, Benson L, Sidach S, Xiao Y, Hammond PS. Discovery of (2 S, 3 R)-N-[2-(Pyridin-3-ylmethyl)1-azabicyclo [2.2. 2] oct-3-yl] benzo [b] furan-2-carboxamide (TC-5619), a selective $\alpha 7$ nicotinic acetylcholine receptor agonist, for the treatment of cognitive disorders. J Med Chem 2012:55(22):9793-9809.

15. Kishida T, Nagamoto $M$, Ohtsu Y, Watakabe M, Ohshima D, Nashiki K, Mizushige T, Izumi T, Obata A, Ebihara K. Lack of an inducible effect of dietary soy isoflavones on the mRNA abundance of hepatic eytochrome P-450 isozymes in rats. Biosei Biotechnol Biochem 2004:68(3):508-515.

16. Parikh S, Ouedraogo JB, Goldstein JA, Rosenthal PJ, Kroetz DL. Amodiaquine metabolism is impaired by common polymorphisms in CYP2C8: implications for malaria treatment in Africa. Clin Pharmacol Ther 2007:82(2):197-203.

17. Gil JP. Amodiaquine pharmacogenetics. Pharmacogenomics 2008:9(10):1385-90.

18. Ishikawa C, Ozaki H, Nakajima T, Ishii T, Kanai S, Anjo S, Shirai K, Inoue I. A frameshift variant of CYP2C8 was identified in a patient who suffered from rhabdomyolysis after administration of cerivastatin. J Hum Genet 2004:49(10):582-585.

19. Staffa JA, Chang J, Green L. Cerivastatin and reports of fatal rhabdomyolysis. N Engl J Med 2002:346(7):539-540.

20. Meunier V, Bourrie M, Julian B, Marti E, Guillou F, Berger Y, Fabre G. Expression and induction of CYP1A1/1A2, CYP2A6 and CYP3A4 in primary cultures of human hepatocytes: a 10-year follow-up. Xenobiotica 2000:30(6):589-607.

21. Malaiyandi V, Lerman C, Benowitz NL, Jepson C, Patterson F, Tyndale RF. Impact of CYP2A6 genotype on pretreatment smoking behaviour and nicotine levels from and usage of nicotine replacement therapy. Mol Psychiatry 2006:11(4):400-409.

22. Pitarque $M$, von Richter $O$, Oke $B$, Berkkan H, Osearson M, Ingelman-Sundberg M. Identification of a single nucleotide polymorphism in the TATA box of the CYP2A6 gene: impairment of its promoter activity. Biochem Biophys Res Commun 2001:284(2):455-460.

23. Tani N, Juvonen RO, Raunio H, Fashe M, Leppänen J, Zhao B, Tyndale RF, Rahnasto-Rilla M. Rational design of novel CYP2A6 inhibitors. Bioorg Med Chem 2014:22(23):6655-6664.

24. Pearce RE, Vakkalagadda GR, Leeder JS. Pathways of carbamazepine bioactivation in vitro I. Characterization of human cytochromes $\mathrm{P} 450$ responsible for the formation of 2-and 3-hydroxylated metabolites. Drug Metab Dispos 2002:30(11):1170-1179.

25. Wypasek E, Branicka A, Awsiuk M, Sadowski J, Undas A. Genetic determinants of acenocoumarol and warfarin maintenance dose requirements in Slavic population: a potential role of CYP4F2 and GGCX polymorphisms. Thromb Res 2014:134(3):604-609.

26. Kupstyte N, Zaliunas R, Tatarunas V, Skipskis V, Zaliaduonyte-Peksiene D, Grabauskyte I, Dovidaitiene D, Bumblauskas K, Gustiene O, Lesauskaite V. Effect of clinical factors and gene polymorphism of CYP2C19*2," 17 and CYP4F2* 3 on early stent thrombosis. Pharmacogenomics 2015:16(3):181-189.

27. van Schie RM, Aoussar A, van der Meer FJ, De Boer A, Maitland-van der Zee AH. Evaluation of the effects of single-nucleotide polymorphisms in CYP3A4 and CYP4F2 on stable phenprocoumon and acenocoumarol maintenance doses. J Thromb Haemost 2013:11(6):1200-3.

28. Deeken JF, Cormier T, Price DK, Sissung TM, Steinberg SM, Tran K, Liewehr DJ, Dahut WL, Miao X, Figg WD. A pharmacogenetic study of docetaxel and thalidomide in patients with castration-

Vol. 62(4): 316 - 324, 2021 
resistant prostate cancer using the DMET genotyping platform. Pharmacogenomics J 2010:10(3):191-199.

29. Tsambaos D, Bolsen K, Georgiou S, Monastirli A, Goerz G. Effects of oral thalidomide on rat liver and skin microsomal P450 isozyme activities and on urinary porphyrin excretion: interaction with oral hexachlorobenzene. Arch Dermatol Res 1994:286(6):347-349.

30. Marez D, Sabbagh N, Legrand M, Lo-Guidice JM, Boone P, Broly F. A novel CYP2D6 allele with an abolished splice recognition site associated with the poor metabolizer phenotype. Pharmacogenetics 1995: 5(5):305-311.

31. Cusato J, Allegra $\mathrm{S}$, De Nicolò A, Boǵlione L, Fatiguso G, Abdi AM, Cariti G, Di Perri G, D'Avolio A. Intracellular and plasma trough concentration and pharmacogenetics of telaprevir. J Pharm Pharm Sci 2015:18(2):171-6.

32. Allegra $S$, Cusato $J$, De Francia S, Arduino A, Longo F, Pirro E, Massano D, De Nicolò A, Piga A, D'avolio A. Role of CYP24A1, VDR and GC gene polymorphisms on deferasirox pharmacokinetics and clinical outcomes. Pharmacogenomics J 2018:18(3):506-515.
33. Ferla S, Aboraia AS, Brancale A, Pepper CJ, Zhu J, Ochalek JT, DeLuca HF, Simons C. Small-molecule inhibitors of 25-hydroxyvitamin D-24-hydroxylase (CYP24A1): synthesis and biological evaluation. J Med Chem 2014: 57 (18):7702-7715.

34. Relats C, Sadeghi-Reeves L, Zbären E, Jenzer H. The role of food-drug-cytochrome P450 interactions in breast cancer. Med Sci Rev 2018: (5):25-34.

35. Hatami N, Ahi S, Sadeghinikoo A, Foroughian M, Javdani F, Kalani N, Fereydoni M, Keshavarz P. Worldwide ACE (I/D) polymorphism may affect COVID-19 recovery rate: an ecological meta-reǵression. Endocrine 2020; 68:479-484.

36. Parsa S, Mogoharab V, Ebrahimi M, Ahmadi SR, Shahi B, Mehramiz NJ, Foroughian M, Zarenezhad M, Kalani N, Abdi MH, Javdani F. COVID-19 as a worldwide selective event and bitter taste receptor polymorphisms: An ecological correlational study. Int J Biol Macromol 2021;177:204-210. 